\title{
Tumor cell dissemination in colon cancer does not predict extrahepatic recurrence in patients undergoing surgery for hepatic metastases
}

\author{
KATJA SCHOPPMEYER ${ }^{1}$, NILS FRÜHAUF ${ }^{2}$, KARL OLDHAFER ${ }^{2}$, \\ SIEGFRIED SEEBER $^{1}$ and SABINE KASIMIR-BAUER ${ }^{1}$ \\ ${ }^{1}$ Department of Internal Medicine (Cancer Research), West German Cancer Center; ${ }^{2}$ Center of General \\ and Transplantation Surgery, University of Essen, Essen, Germany
}

Received May 3, 2005; Accepted June 24, 2005

\begin{abstract}
Patients undergoing resection of hepatic metastases of colorectal cancer have a high risk of extrahepatic recurrence, most likely caused by early tumor cell dissemination or the manipulation of liver tumors during surgical resection. Using immunocytochemistry, we studied 47 patients for cytokeratin (CK)-positive $(+)$ cells in: a) bone marrow (BM) samples to determine whether tumor cell dissemination had already occurred before surgery; and b) blood samples directly taken from the hepatic vein before and during surgery of liver metastases. In addition, normal and malignant liver tissues were evaluated for markers known to be involved in tumor progression and metastasis [urokinase plasminogen activator (uPA), Her-2/neu, epidermal growth factor receptor (EGF-R)] using sandwich enzyme immunoassays. $\mathrm{CK}^{+}$cells were detected in the BM of $26 / 47$ patients $(55 \%)$, in blood samples of $14 / 47$ patients $(30 \%)$ before surgery and $11 / 47$ patients $(23 \%)$ during surgery with a median detection rate of 1 (range, 1-14) $\mathrm{CK}^{+}$cell per $4 \times 10^{6} \mathrm{MNC}$. No $\mathrm{CK}^{+}$cells were found in $15 / 47$ patients $(32 \%)$ in any sample studied. Tumor tissue was obtained from 32/47 patients and normal liver tissue from $24 / 32$ patients. While no differences were found for EGF-R and Her-2/neu, a 9-fold higher expression of uPA could be demonstrated in tumor tissue of 20/32 patients (63\%) compared to normal liver tissue. When all obtained results were correlated with clinical outcome, neither the detection of $\mathrm{CK}^{+}$cells nor the expression pattern in the tumor tissue, or the combination of both, was predictive for extra-
\end{abstract}

Correspondence to: Dr Sabine Kasimir-Bauer, Universitätsklinikum Essen, Frauenklinik, Hufelandstr. 55, 45122 Essen, Germany

E-mail: sabine.kasimir-bauer@uni-essen.de

Abbreviations: BM, bone marrow; CK, cytokeratin; EGF-r, epidermal growth factor-receptor; Mab, monoclonal antibody; MNC, mononuclear cells; PBS, phosphate-buffered saline; uPA, urokinase plasminogen activator

Key words: cytokeratin-positive cells, liver metastases, urokinase plasminogen activator, epidermal growth factor receptor, Her-2/neu hepatic recurrence or overall survival after a mean observation time of 43 months (range, 26-54 months). Although $\mathrm{uPa}$ is overexpressed in liver metastases of colorectal cancer, and dissemination of $\mathrm{CK}^{+}$cells during surgery of these metastases is a frequent event in colon cancer, these findings do not predict extrahepatic recurrence. Further characterization of single cells, especially those spread during surgery, will help to identify those patients with an increased risk of later relapse.

\section{Introduction}

Taken together, tumors of the colon and rectum represent the second leading cause of cancer deaths in Western societies. Patients presenting with resectable tumors are considered to have a low risk of tumor recurrence. However, $30-40 \%$ of these patients with surgically resectable tumors subsequently develop metastases both locally and at distant locations $(1,2)$. The major reason for relapse seems to be the hematogenous or lymphatic spread of occult tumor cells, which can arise before diagnosis at an early stage of primary tumor growth or occurs during the manipulation of tumors during surgical resection. Since this tumor cell spread is regularly underestimated by currently available clinical and pathological staging procedures, sensitive immunohistochemical and molecular techniques were developed to facilitate the detection of isolated carcinoma cells in blood, bone marrow (BM) or lymph nodes using monoclonal antibodies (Mab) against epithelium-specific proteins $(3,4) . \mathrm{CK}^{+}$cells were detected in the BM of patients with colorectal cancer, and their presence has been associated with a significantly higher relapse rate $(5,6)$. Furthermore, CK-20 RT-PCR transcripts in peritumoral histopathologic tumor-free (pN0) lymph nodes of colorectal cancer patients were shown to be an independent prognostic factor for overall survival $(7,8)$. CK-20 RT-PCR transcripts were even found in the blood and BM during surgery of colorectal cancer (9).

One of the major metastatic sites in colon cancer is the liver, as a result of the portal venous drainage of the gastrointestinal tract. Since liver mobilization is essential for the occlusion of liver vessels, the no-touch resection technique cannot be applied. Thus, these patients have a high 
Table I. Comparison of cytokeratin-positive cells in blood and bone marrow samples of patients with liver metastases of colorectal cancer.

\begin{tabular}{lcc}
\hline & \multicolumn{2}{c}{ Blood } \\
\cline { 2 - 3 } Bone marrow & $\begin{array}{c}\text { Positive } \\
19 / 47(40 \%)\end{array}$ & $\begin{array}{c}\text { Negative } \\
28 / 47(60 \%)\end{array}$ \\
\hline Positive, 26/47 (55\%) & $13 / 47(28 \%)$ & $13 / 47(28 \%)$ \\
Negative, 21/47 (45\%) & $6 / 47(12 \%)$ & $15 / 47(32 \%)$ \\
\hline
\end{tabular}

risk for extrahepatic tumor recurrence as a result of tumor cell dissemination during surgery, most likely caused by mechanical alteration of liver tumors located adjacent to the liver vein. Weitz et al demonstrated that CK-20 RT-PCR transcripts were significantly more often detected in blood samples taken from the central vein during surgery than before and after surgery of liver metastases of colorectal patients, suggesting that liver resection carries an increased risk for intraoperative tumor cell dissemination (10).

Since placing liver vein and vena cava inferior catheters is routinely established (11), studying tumor cell dissemination in blood taken from these catheters during surgery should be more precise.

Using an immunocytochemical standard method proven to be reliable and sensitive for the detection of rare CK 8-, $18-$, and 19-positive cells in a variety of solid tumors $(3,5)$, we analyzed the extent of these cells in BM samples before surgery and in blood samples directly taken from the hepatic vein before and during surgery of colon cancer patients undergoing resection of hepatic metastases. Applying enzyme immunolinked assays (ELISA), normal and tumor liver tissues were analyzed for the expression of the urokinase plasminogen activator (uPA), Her-2/neu and epidermal growth factor receptor (EGF-R), known to be involved in tumor progression and metastasis (12-14). The purpose of this study was to determine whether tumor cell dissemination of $\mathrm{CK}^{+}$cells during surgery can predict extrahepatic recurrence.

\section{Patients and methods}

Patients. A total of 47 patients ( 25 male; 22 female) with a median age of 61 years (range, 33-88 years) and newly diagnosed hepatic metastases of colorectal cancer were included in the study after written informed consent. The primary colon carcinomas were staged as $\mathrm{T}_{2-4} \mathrm{~N}_{0-2} \mathrm{M}_{0-2}$. The mean observation time was 43 months (range, 26-54 months).

Study design. BM taken before surgery of liver metastases was analyzed for $\mathrm{CK}^{+}$cells to determine whether dissemination of these cells had already occurred. To study dissemination during surgery, blood samples were taken directly from the hepatic vein during surgery. Results were compared to blood samples from the hepatic vein taken before surgery. In order to characterize liver metastases, normal liver and tumor tissue were analyzed for expression of uPA, Her-2/neu, and EGF-r known to be associated with an increased risk for progression in colorectal cancer.
Table II. Distribution of cytokeratin-positive cells in bone marrow and blood samples taken before and during surgery.

\begin{tabular}{ccccc}
\hline \multicolumn{2}{c}{ Blood } & & & \\
\hline Before & During & & Bone & All \\
surgery & surgery & marrow & patients \\
\hline- & - & - & $15 / 47(32 \%)$ \\
+ & + & + & $6 / 47(13 \%)$ \\
- & - & + & $13 / 47(28 \%)$ \\
+ & + & - & $0 / 47(0 \%)$ \\
- & + & + & $3 / 47(6 \%)$ \\
+ & - & + & $4 / 47(9 \%)$ \\
- & + & - & $2 / 47(4 \%)$ \\
+ & - & - & $4 / 47(9 \%)$ \\
\hline
\end{tabular}

Bone marrow samples. BM samples $(10 \mathrm{ml})$ were obtained after induction of general anesthesia by aspiration from both iliac crests by needle aspiration under the conditions of normal coagulation parameters.

Blood samples. Blood samples $(27 \mathrm{ml})$ were taken from the hepatic vein before and during surgery.

Preparation of bone marrow and blood. Mononuclear cells (MNC) were isolated from heparinized BM (5000 U/ml BM) and blood (EDTA) by Ficoll-Hypaque density gradient centrifugation (density $1.077 \mathrm{~g} / \mathrm{mol}$; Pharmacia, Freiburg, Germany) at $400 \mathrm{x}$ g for $30 \mathrm{~min}$. Interface cells were washed (400 x $\mathrm{g}$ for $15 \mathrm{~min}$ ) and resuspended in phosphate-buffered saline (PBS). A total of $6-8 \times 10^{6}$ cells $\left(1 \times 10^{6}\right.$ per slide $)$ of each $\mathrm{BM}$ aspiration were directly spun onto glass slides (400 x g for $5 \mathrm{~min}$ ) coated with poly-L-lysine (Sigma, Deisenhofen, Germany) using a Hettich centrifuge (Tuttlingen, Germany).

Preparation of liver tissue specimens. The frozen specimens were sliced into small pieces, weighed and supplemented with cold buffer containing $10 \mathrm{mM}$ Tris- $\mathrm{HCl}(\mathrm{pH} 7.4), 1.5 \mathrm{mM}$ EDTA, $10 \%$ glycerol, $0.1 \%$ sodium azide and an effective cocktail of protease inhibitors $(0.5 \mu \mathrm{g} / \mathrm{ml}$ leupeptin, $1 \mu \mathrm{g} / \mathrm{ml}$ pepstatin and $0.2 \mathrm{mM}$ pA-PMSF). After homogenization on ice using a Polytron homogenizer (30 W, Sonifier B-12; Branson Sonic Power Company, Danbury, CT, USA) with two 5-sec bursts at half speed (setting 6), $50 \mu 1$ of the homogenate was mixed with $10 \mu 1$ PBS containing 6\% Triton-X-100 and incubated for $5 \mathrm{~min}$ at room temperature. Subsequently, the samples were centrifuged at 14,000 $\mathrm{xg}$ for $10 \mathrm{~min}$, and the protein content of the supernatant was determined according to Lowry et al, using bovine serum albumin as a standard (15).

Immunocytochemistry. After air drying overnight, staining for $\mathrm{CK}^{+}$cells was performed as described (16) using the Epimet $^{\circledR}$ kit (Micromet, Munich, Germany). The detection of epithelial cells using this kit is based on the reactivity of the murine Mab A45-B/B3, directed against a common epitope of CK polypeptides. The kit uses Fab fragments of the pan- 
Table III. Correlation between clinical follow-up and detected cytokeratin-positive cells after a median observation time of 43 months (range, 25-52 months).

\begin{tabular}{|c|c|c|c|c|c|c|}
\hline Health state & $\begin{array}{l}\text { No. of } \\
\text { patients }\end{array}$ & $\begin{array}{l}\mathrm{CK}^{+} \text {cells } \\
\text { detected }\end{array}$ & $\begin{array}{c}\mathrm{CK}^{+} \text {cells } \\
\text { detected } \\
\text { in } \mathrm{BM}\end{array}$ & $\begin{array}{c}\mathrm{CK}^{+} \text {cells } \\
\text { detected in } \\
\text { blood samples } \\
\text { before surgery }\end{array}$ & $\begin{array}{c}\mathrm{CK}^{+} \text {cells } \\
\text { detected in } \\
\text { blood samples } \\
\text { during surgery }\end{array}$ & $\begin{array}{c}\text { Overall } \\
\text { survival } \\
\text { (months) }\end{array}$ \\
\hline Alive without recurrence & 15 & $10 / 15(67 \%)$ & $8 / 15(53 \%)$ & $5 / 15(33 \%)$ & $4 / 15(27 \%)$ & $43(26-54)$ \\
\hline Deceased & 15 & $11 / 15(73 \%)$ & $7 / 15(47 \%)$ & $5 / 15(33 \%)$ & $4 / 15(27 \%)$ & $19(7-32)$ \\
\hline
\end{tabular}

Mab complexed with alkaline phosphatase molecules. Briefly, the method includes: a) permeabilization of the cells with a detergent for $5 \mathrm{~min}$; b) fixation with a formaldehyde-based solution for $10 \mathrm{~min}$; c) binding of the conjugate Mab A45-B/ B3-alkaline phosphatase to cytoskeletal CKs for $45 \mathrm{~min}$; and d) formation of an insoluble red reaction product at the site of binding of the specific conjugate for $15 \mathrm{~min}$. Subsequently, the cells were counterstained with Mayer's hematoxylin for 1 min and mounted with aqueous permanent mounting medium containing $15 \mathrm{mM} \mathrm{NaN}_{3}$ (Dako, Hamburg, Germany). A negative control antibody (conjugate of Fab fragment; Micromet) served as a negative control for all patients. For each test, a positive control slide with the colon carcinoma cell line HT-29 was treated under the same conditions. The microscopic evaluation was carried out independently by two investigators.

Determination of Her-2/neu, EGF-r and uPA. Protein (10$20 \mu \mathrm{g}$ ) from the liver tissue preparations were used to determine the oncoprotein Her-2/neu with the Her-2/neu (c-erbB-2) sandwich enzyme immunoassay (Oncogene Science, Cambridge, MA), which utilizes a mouse Mab for capture and a different biotinylated mouse Mab for the detection of human neu protein. Both capture and detector reagents specifically bind to the extracellular domain of neu protein. Values exceeding the 3 -fold standard deviation value of normal liver tissue results were defined as overexpression of Her-2/neu.

To determine the EGF-r, protein $(40 \mu \mathrm{g})$ from the liver tissue preparations were used with the sandwich type immunoassay (Oncogene Science), which utilizes a mouse Mab as a detector. Both capture and detector reagents specifically recognize the extracellular domain of the EGF-r. Values exceeding the 3 -fold standard deviation value of normal liver tissue results were defined as overexpression of EGF-r.

Protein $(40 \mu \mathrm{g})$ from the liver tissue preparations were used to determine uPA with the uPA sandwich enzyme immunoassay (Oncogene Science), which utilizes two Mabs to human uPA as the capture reagents, immobilized on the interior surface of microplate wells. According to the distributors' recommendations, the cut-off values were defined at $1500 \mathrm{pg} / \mathrm{ml}$ for male and $2100 \mathrm{pg} / \mathrm{ml}$ for female patients.

Evaluation of data and statistics. Patients were evaluated as tumor cell-positive if at least one $\mathrm{CK}^{+}$cell was detected as analyzed by immunocytochemistry. The Mann-Whitney rank-sum test was used to calculate the data of the ELISA assays.

\section{Results}

Specificity for immunocytochemistry. The applied antibody $\mathrm{A} 45-\mathrm{B} / \mathrm{B} 3$ for the detection of $\mathrm{CK}^{+}$cells is directed against a common epitope of CK polypeptides and complexed with alkaline phosphatase anti-alkaline phosphatase (APAAP) molecules, and thus the missing Fc part prevents unspecific binding of the antibody to Fc receptors on MNC. A BM analysis of 165 non-carcinoma control patients resulted in only 2 false-positive results indicating that the A45B/B-3 gives reliable results for the detection of single-disseminated tumor cells (17).

Distribution of CK-positive cells in BM and blood samples. Table I shows the detection rate of $\mathrm{CK}^{+}$cells in $\mathrm{BM}$ and blood samples. In total, $\mathrm{CK}^{+}$cells were detected in the $\mathrm{BM}$ of $26 / 47$ patients $(55 \%)$ and in blood samples of $19 / 47$ patients (40\%) with a median detection rate of 1 (range, 1-14) $\mathrm{CK}^{+}$ cell per $4 \times 10^{6} \mathrm{MNC}$. In $13 / 47$ patients $(28 \%), \mathrm{CK}^{+}$cells were detected in the BM and respective blood samples. In 13/47 patients $(28 \%), \mathrm{CK}^{+}$cells were only detected in the $\mathrm{BM}$; in $6 / 47$ patients $(12 \%), \mathrm{CK}^{+}$cells were only found in blood samples. No $\mathrm{CK}^{+}$cells were found in $15 / 47$ patients $(32 \%)$ at any time point studied.

A more detailed analysis for the distribution of $\mathrm{CK}^{+}$cells is given in Table II, which shows the spread of $\mathrm{CK}^{+}$cells in correlation with potential cases of detection possibilities. In $15 / 47$ patients $(32 \%)$, no $\mathrm{CK}^{+}$cells were found in any sample studied; in $6 / 47$ patients $(13 \%), \mathrm{CK}^{+}$cells were detected. In $13 / 47$ patients $(28 \%), \mathrm{CK}^{+}$cells were only detected in the BM. In $3 / 47$ patients $(6 \%), \mathrm{CK}^{+}$cells were found in the $\mathrm{BM}$ and blood samples during surgery; in $4 / 47$ patients $(9 \%), \mathrm{CK}^{+}$ cells could be detected in BM and blood samples before surgery. In all other cases, $\mathrm{CK}^{+}$cells were only obtained in blood samples before or during surgery.

Table III shows the correlation between the detection of $\mathrm{CK}^{+}$cells and a clinical follow-up after a median observation time of 43 months (range, 25-52 months). $\mathrm{CK}^{+}$cells were detected in 10/15 (67\%) patients who are still alive without recurrence [OS 43 months (range 26-54 months)] and in 11/15 (73\%) patients who died [OS 19 months (range, 7-32 months)]. No differences were found when the number of $\mathrm{CK}^{+}$cells in $\mathrm{BM}$ and blood samples taken before or during surgery were 


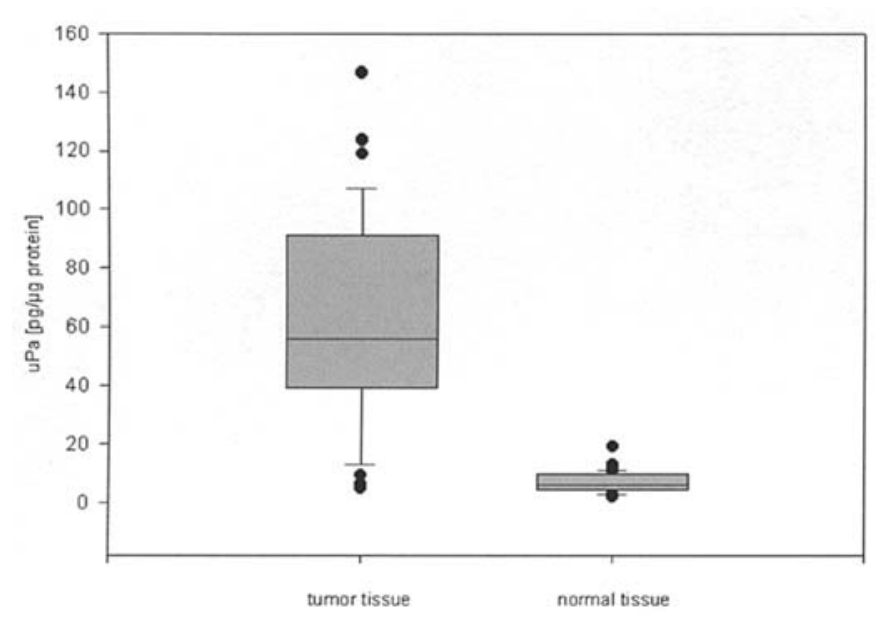

Figure 1. Comparison of detected uPA amounts in normal liver tissue and liver metastases. Sigma Plot, data shown as median with a 25 th percentile (grey box).

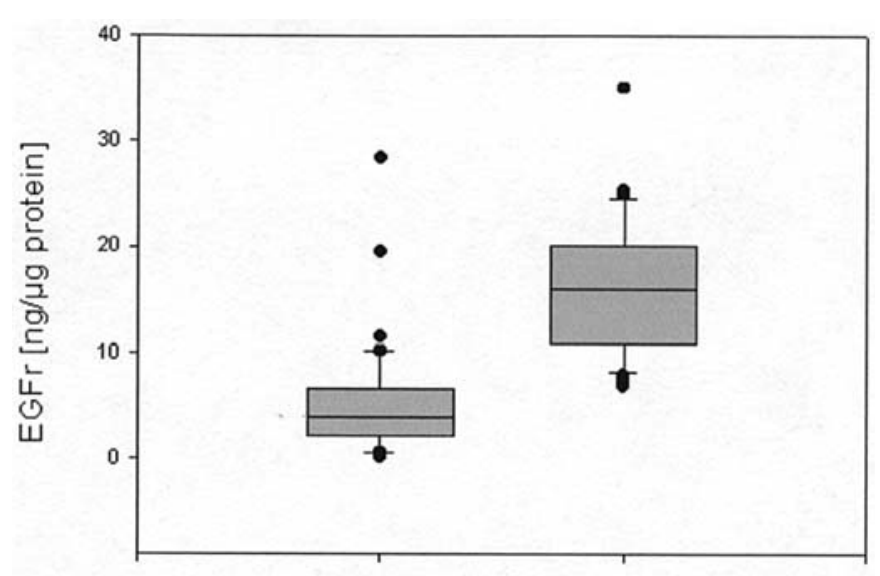

tumor tissue normal tissue

Figure 2. Comparison of detected EGF-r amounts in normal liver tissue and liver metastases. Sigma Plot, data shown as median with a 25 th percentile (grey box).

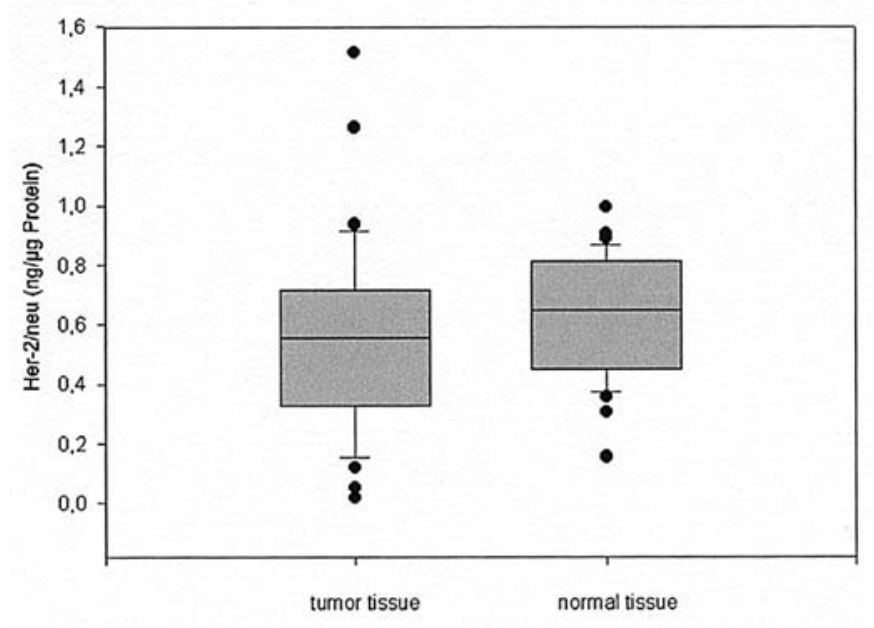

Figure 3. Comparison of detected Her-2/Neu amounts in normal liver tissue and liver metastases. Sigma Plot, data shown as median with a 25 th percentile (grey box). compared in both patient groups. Eleven patients were lost in follow-up, 3 are alive with recurrence and 3 died of surgical reasons.

Distribution of EGF-r, uPA and Her-/neu in normal and tumor liver tissue. We further analyzed normal and tumor tissue of the liver for the expression of uPA (Fig. 1), EGF-r (Fig. 2) and Her-2 neu (Fig. 3). Tumor tissue could be obtained from 32/47 patients and normal liver tissue from 24 of these 32 patients. Whereas no differences were found for EGF-R and Her-2/neu, uPA was markedly enhanced in tumor tissue of 22/35 patients (mean, $283 \mathrm{pg} / \mathrm{ml}$; range, $88-765 \mathrm{pg} / \mathrm{ml}$; $\mathrm{p} \leq 0.001$ ) compared to normal tissue (mean, $2561 \mathrm{pg} / \mathrm{ml}$; range, 204-5864 pg/ml).

EGF-r was not found to be significantly higher in normal tissue (mean, $647 \mathrm{ng} / \mathrm{ml}$; range, 275-1400 $\mathrm{ng} / \mathrm{ml}$ ) compared to tumor tissue (mean, 210; range, 5-1136 ng/ml; p $\leq 0.001$ ). Although the mean values for Her-2/neu in normal tissue (mean, $0.609 \mathrm{ng} / \mu \mathrm{g}$; range, 0.306-0.903 ng/ $\mu \mathrm{g}$ ) were comparable to those in tumor tissue (mean, $0.595 \mathrm{ng} / \mu \mathrm{g}$; range, $0.156-1.512 \mathrm{ng} / \mu \mathrm{g}$ ), significant differences in expression were found in 15/32 (47\%) patients. A comparison of normal and malignant tissue in these 15 patients resulted in markedly higher Her-2/neu values in normal tissue in 9/15 patients $(60 \%)$, and markedly enhanced values in tumor tissue were found in $6 / 15$ patients $(40 \%)$.

When all obtained results were correlated with clinical outcome, neither the detection of $\mathrm{CK}^{+}$cells nor the expression pattern in the tumor tissue, or the combination of both, was predictive for extrahepatic recurrence or overall survival (Table IV).

\section{Discussion}

Despite a potential curability rate of $\geq 70 \%$ for patients suffering from colon cancer, the overall 5-year survival rate is just over $30 \%(1,2)$. Although many patients present with tumors that are surgically resectable, a large number of patients die from recurrent disease after apparently curative surgery. Due to the development of surgical resection techniques, even a small number of patients with recurrent disease may be cured by salvage resection of pulmonary or hepatic metastases. A bi-institutional analysis documented that patients with low tumor load are the best candidates for repeat liver resection and postulated liver resections that are safe for colorectal liver metastases (18). However, applying these techniques results in recurrences both locally and at distant locations. The main reason for relapse seems to be the hematogenous or lymphatic spread of occult tumor cells, which can arise before diagnosis at an early stage of primary tumor growth or the manipulation of tumors during surgical resection. Although a broad range of studies on tumor cell detection in the BM and blood of patients with solid tumors have shown the significance of these cells as a predictor for decreased disease-free and overall survival $(3,4)$, little is known about tumor cell dissemination during surgery.

Here, we demonstrate that although tumor cell dissemination had taken place before surgery in $55 \%$ of the patients, the spread of $\mathrm{CK}^{+}$cells during surgery of hepatic metastases seems to be a frequent event. Whether these cells 
Table IV. Correlation between increased uPA expression clinical follow-up and detected cytokeratin-positive cells after a median observation time of 43 months (range, 25-52 months).

\begin{tabular}{lccccc}
\hline Health state & $\begin{array}{c}\text { No. of } \\
\text { patients }\end{array}$ & $\begin{array}{c}\text { Increased uPA } \\
\text { expression }\end{array}$ & $\begin{array}{c}\text { Increased uPA } \\
\text { expression and } \\
\mathrm{CK}^{+} \text {cells detected }\end{array}$ & $\begin{array}{c}\mathrm{CK}^{+} \text {cells } \\
\text { detected }\end{array}$ & $\begin{array}{c}\text { Overall } \\
\text { survival } \\
\text { (months) }\end{array}$ \\
\hline Alive without recurrence & 12 & $8 / 12(67 \%)$ & $5 / 12(42 \%)$ & $8 / 12(67 \%)$ & $44(26-54)$ \\
Deceased & 10 & $5 / 10(50 \%)$ & $5 / 10(50 \%)$ & $10 / 10(100 \%)$ & $23(7-32)$ \\
\hline
\end{tabular}

are responsible for a later relapse must be determined since no differences could be obtained when the detection rate of $\mathrm{CK}^{+}$cells in the survivor group was compared with those patients who died. Similar conclusions were demonstrated by Velms et al, who showed no correlation between CK-20 positivity in blood or bone marrow and later extrahepatic tumor recurrence (26).

Only a few reports have previously analyzed tumor cell dissemination during surgery of colorectal cancer. The most extensive studies were performed by Weitz et al using RTPCR for the detection of CK-20 transcripts in blood, BM and lymph nodes of patients undergoing surgery of colorectal tumors, as well as resection of liver metastases of colorectal cancer $(7,9,10)$. By analyzing apical lymph nodes, they demonstrated that lymphogenic tumor cell dissemination is a common and frequent event in colorectal cancer preceding hematogenic tumor cell dissemination (7). Furthermore, tumor cells were detected significantly more often during surgery than before and after surgery suggesting, that liver resection carries an increased risk for intraoperative tumor cell dissemination. In a comparative analysis of tumor cell dissemination in different blood compartments, the detection rate of CK-20 RT-PCR transcripts was significantly higher in mesenteric venous blood $(p<0.001)$ than that in central and peripheral blood taken from patients with colorectal cancer (19). In our studies, $\mathrm{CK}^{+}$cells were more often found before surgery. The detection rate of $55 \%$ for $\mathrm{CK}^{+} \mathrm{BM}$ cells seems to be high at first view when compared to other published studies using immunocytochemistry for the detection of $\mathrm{CK}^{+}$ cells, but this discrepancy can be explained by the number of cells analyzed. While Schlimok et al screened $1.5 \times 10^{5} \mathrm{BM}$ cells resulting in a detection rate of $26.9 \% \mathrm{CK}^{+}$cells, and Lindemann et al found $31.9 \% \mathrm{BM}$ samples to be $\mathrm{CK}^{+}$when $3 \times 10^{5}$ cells were analyzed, we used more than $1 \times 10^{7} \mathrm{BM}$ cells for the screening of $\mathrm{CK}^{+}$cells. The differences in the detection rate of $\mathrm{CK}^{+}$cells during surgery may be due to the different concepts of evaluation in each study. Weitz et al analyzed blood taken from a central venous catheter, whereas blood from the hepatic vein was used in our setting. Blood directly taken from the hepatic vein, during time points when the liver is mostly mobilized, might be more precise for the determination of tumor cell dissemination during surgery, although the right time point of blood collection for obtaining $\mathrm{CK}^{+}$cells cannot be defined and may just be by chance. Differences in results may also be caused by the different methods used. Whereas Weitz et al applied RT-PCR for the detection of CK-20 transcripts, we used CK-based immunocytochemistry, currently the standard method for the detection of $\mathrm{CK}^{+}$cells. As shown by a profound methodological analysis (3), this immunocytochemical assay offers a well-established method for detecting CK-epitopes found on rare epithelial cells, but not on autochthonous BM cells in a variety of solid tumors $(17,20-22)$.

No previous characterization of $\mathrm{CK}^{+}$cells spread during surgery of colorectal tumors or hepatic metastases has been reported. For the reliable quantification of tumor-associated antigens present on the cell surface of $\mathrm{CK}^{+}$cells, a tumor load of $>5 \mathrm{CK}^{+}$cells per $10^{6} \mathrm{BM}$ cells is necessary (21). Due to the low number of detected $\mathrm{CK}^{+}$cells $\left[1\right.$ (range 1-14) $\mathrm{CK}^{+}$ cell per $4 \times 10^{6} \mathrm{MNC}$ ], double-labeling experiments for antigen characterization on the cell surface were not possible. Therefore, normal and tumor tissue of the liver were analyzed for the expression of uPa, Her-2/neu and EGF-r known to be involved in metastasis and tumor progression. While no differences were found for EGF-R and Her-2/neu, we were able to detect a 9-fold increased level of uPA in liver metastases in $13 / 21$ patients compared to their normal liver tissue. These findings are comparable with results found in primary colorectal tumors (24) and hepatocellular carcinoma, where the overexpression of uPA has been shown to correlate with invasiveness, metastasis, and prognosis (25).

We conclude that although $\mathrm{uPa}$ is overexpressed in liver metastases of colorectal cancer, and dissemination of $\mathrm{CK}^{+}$ cells during surgery of these metastases is a frequent event in colon cancer, these findings do not predict extrahepatic recurrence. Further characterization of single cells, especially those spread during surgery, will help identify those patients with an increased risk for later relapse.

\section{Acknowledgements}

We thank Karola Schlagheck and Joachim Käding for excellent technical assistance. This work was supported by the Mildred Scheel Stiftung.

\section{References}

1. Deans GT, Parks TG, Rowlands BJ and Spence RAJ: Prognostic factors in colorectal cancer. Br J Surg 79: 608-613, 1992.

2. Liefers J-G, Celton-Jansen A-M, van der Velde CJH, Hermans J, van Krieken JHJM, Cornelisse CJ and Tollenaar RAEM: Micrometastases and survival in stage II colorectal cancer. N Eng J Med 339: 223-228, 1998.

3. Pantel K, Cote RJ and Fodstad O: Detection and clinical importance of micrometastatic disease. J Natl Cancer Inst 91: 1113-1124, 1999.

4. Müller P and Schlimok G: Bone marrow 'micrometastases' of epithelial tumors: detection and clinical relevance. J Cancer Res Clin Oncol 126: 607-618, 2000. 
5. Schlimok G, Funke I, Bock B, Schweiberer B, Witte J and Riethmüller G: Epithelial tumor cells in bone marrow of patients with colorectal cancer: immunocytochemical detection, phenotypic characterization, and prognostic significance. J Clin Oncol 8: 831-837, 1990 .

6. Lindemann F, Schlimok G, Dirschedl P, Witte J and Riethmüller G: Prognostic significance of micrometastatic tumour cells in bone marrow of colorectal cancer patients. Lancet 340: 685-689, 1992.

7. Weitz J, Kienle P, Magener A, Koch M, Schrödel A, Willeke F, Autschbach F, Lacroix J, Lehnert T, von Knebel Doeberitz M and Herfarth C: Detection of disseminated colorectal cancer cells in lymph nodes, blood and bone marrow. Clin Cancer Res 5: 1830-1836, 1999.

8. Rosenberg R, Hoos A, Müller J, Baier P, Stricker D, Werner M, Nekarda H and Siewert J-R: Prognostic significance of cytokeratin-20 reverse transcriptase polymerase chain reaction in lymph nodes of node-negative colorectal cancer patients. J Clin Oncol 20: 1049-1055, 2002.

9. Weitz J, Kienle P, Lacroix J, Willeke F, Benner A, Lehnert T, Herfarth $C$ and von Knebel Doeberitz M: Dissemination of tumor cells in patients undergoing surgery for colorectal cancer. Clin Cancer Res 4: 343-348, 1998.

10. Weitz J, Koch M, Kienle P, Schrödel A, Willeke F, Benner A, Lehnert T, Herfarth C and von Knebel Doeberitz M: Detection of hematopoetic tumor cell dissemination in patients undergoing resection of liver metastases of colorectal cancer. Ann Surg 232: 66-72, 2000.

11. Höltje M, Mahr KH and Bornscheuer A: Der Lebervenenkatheter als Ergänzung des Monitorings bei Hemihepatektomien. Anästhesiol Intensivmed Notfallmed Schmerzther 32: 112, 1997.

12. Skelly MMA, Troy MJ, Duffy HE, Mulcahy HE, Duggan C, Connel TG, O'Donoghue DP and Sheahan K: Urokinase-type plasminogen activator in colorectal cancer: relationship with clinicopathological features and patient outcome. Clin Cancer Res 3: 1837-1840, 1997

13. Osako T, Miyahara M, Uchino S, Inomata M, Kitano S and Kobayashi M: Immunohistochemical study of c-erbB-2 protein in colorectal cancer and correlation with patient survival. Oncology 55: 548-555, 1998.

14. Ciradello F, Kim N, Saeki T, Dono R, Persico MG, Plowman GD, Garrigues J, Radke S, Todaro GJ and Salomon DS: Differential expression of epidermal growth factor-related proteins in human colorectal tumors. Proc Natl Acad Sci USA 88: 7792-7796, 1991.

15. Lowry OH, Rosenbrough NJ, Farr AL and Randall RJ: Protein measurement with the Folin phenol reagent. J Biol Chem 193: 265-275, 1951.

16. Braun S and Pantel K: Micrometastatic bone marrow involvement: detection and prognostic significance. Med Oncol 16: 154-165, 1999.
17. Braun S, Müller P, Hepp F, Schlimok G, Riethmüller G and Pantel K: Micrometastatic breast cancer cells in bone marrow at primary surgery: prognostic value in comparison with nodal status. J Natl Cancer Inst 90: 1099-1101, 1998.

18. Petrowsky H, Gonen M, Jarmagin W, Lorenz M, DeMatteo R, Heinrich S, Encke A, Blumgart L and Fong Y: Second liver resections are safe and effective treatment for recurrent hepatic metastases from colorectal cancer. Ann Surg 235: 863-871, 2002.

19. Koch M, Weitz J, Kienle P, Benner A, Willeke F, Lehnert T, Herfarth $\mathrm{C}$ and von Knebel Doeberitz M: Comparative analysis of tumor cell dissemination in mesenteric, central, and peripheral venous blood in patients with colorectal cancer. Arch Surg 136: 85-89, 2001

20. Kasimir-Bauer S, Mayer S, Bojko P, Borquez D, Neumann R and Seeber S: Survival of tumor cells in stem cell preparations and bone marrow of patients with high-risk or metastatic breast cancer after receiving dose-intensive or high-dose chemotherapy. Clin Cancer Res 71: 1582-1589, 2001.

21. Kasimir-Bauer S, Oberhoff C, Sliwinska K, Neumann R, Schindler AE and Seeber S: Evaluation of different methods for the detection of minimal residual disease in blood and bone marrow of patients with primary breast cancer: Importance for clinical use? Breast Cancer Res Treat 69: 123-132, 2001.

22. Kasimir-Bauer S, Schleucher N, Weber R, Neumann R and Seeber S: Evaluation of different markers in lung cancer: Prognostic value of clinical staging, tumor cell detection and tumor marker analysis for tumor progression and overall survival. Oncol Rep 10: 475-482, 2003.

23. Fujii T, Obara T, Tanno S, Ura H and Kohgo Y: Urokinase-type plasminogen activator and plasminogen activator inhibitor-1 as a prognostic factor in human colorectal carcinomas. HepatoGastroent 46: 2299-2308, 1999.

24. Zheng Q, Tang Z-Y, Xue Q, Shi D-R, Song H-Y and Tang H-B: Invasion and metastases of hepatocellular carcinoma in relation to urokinase-type plasminogen activator, its receptor and inhibitor. J Cancer Res Clin Oncol 126: 641-646, 2000

25. De Luca A, Pignata S, Casamassimi A, D'Antonio A, Gridelli C, Rossi A, Cremona F, Parisi V, De Matteis A and Normanno N: Detection of tumor cells in carcinoma patients by a novel epidermal growth factor reverse transcription-PCR assay. Clin Cancer Res 6: 1439-1444, 2000.

26. Velms FA, Diepstra JHS, Punt CJA, Ligtenberg MJL, Cornelissen IMHA, van Krieken JHJM, Wobbes T, Rues TJM and van Muijen GNP: Detection of disseminated tumor cells in blood and bone marrow samples of patients undergoing hepatic resection for metastasis of colorectal cancer. Br J Surg 90: 989-995, 2003. 